\title{
ANALISIS KUALITAS AIR SUNGAI KAYAN KABUPATEN SINTANG
}

\author{
Ria Rosdiana Hutagaol \\ Fakultas Pertanian Universitas Kapuas Sintang \\ Email : riarose.h@gmail.com
}

\begin{abstract}
Abstrak : Penelitian ini bertujuan untuk mengetahui kualitas air Sungai Kayan Kabupaten Sintang. Penelitian ini dilakukan pada bulan Juni-Juli 2018 di lima desa yang berada di sepanjang aliran Sungai Kayan yaitu Desa Lintang Tambuk dan Desa Nanga Tebidah yang terdapat di Kecamatan Kayan Hulu dan Desa Nanga Mau, Desa Mentunai, dan Desa Sungai Ranap yang terdapat di Kecamatan Kayan Hilir untuk pengambilan sampel air. Analisa sampel air sungai dilakukan di Laboratorium Lingkungan Badan Lingkungan Hidup Kabupaten Sintang. Berdasarkan hasil analisis air sungai Kayan sesuai PP No. 82 Tahun 2001 tentang Pengelolaan Kualitas Air dan Pengendalian Pencemaran Air secara keseluruhan tampak bahwa kelima desa yang menjadi titik sampling di sepanjang aliran sungai Kayan menunjukkan bahwa untuk parameter Chemical Oxygen Demand (COD), Biologycal Oxygen Demand (BOD), Warna, Kekeruhan, kandungan logam besi $(\mathrm{Fe})$, dan logam timbale $(\mathrm{Pb})$ telah melebihi ambang batas baku mutu kualitas air kelas 1 dan 2. Air sungai Kayan sudah tidak memenuhi kriteria baku mutu air kelas 1 sehingga tidak layak untuk menjadi bahan baku air minum bagi masyarakat setempat.
\end{abstract}

Kata Kunci : Kualitas Air, Sungai Kayan

\section{PENDAHULUAN}

Sungai Kayan termasuk ke dalam DAS Kapuas yang bermuara di Sub DAS Melawi. Sungai Kayan memiliki secara administrasi melewati 2 (dua) kecamatan, yaitu Kecamatan Kayan Hilir dan Kayan hulu. Sungai Kayan memiliki 4 (empat) anak sungai cukup besar, seperti sungai Inggar, sungai Payak, Sungai Kebahan, dan sungai Mau. Dengan kondisi ini, sungai Kayan sangat penting pengaruhnya bagi keberadaan di bebeberapa lokasi anak sungainya maupun dikedua kecamatan tersebut. Oleh dalam melakukan suatu perubahan dalam pola pengelolaan DAS Kapuas, sungai Kayan menjadi pilihan dalam suatu implementasi lebih kecil dengan suatu implikasi yang dapat menjadi rekomendasi dalam pengelolaan DAS.

Sungai Kayan selain berfungsi sebagai sumber kehidupan dan penghidupan, juga terdapat beberapa 
Analisis Kualitas Air Sungai Kayan Kabupaten Sintang

ancaman yang ada di sekitar sungai Kayan. Ancaman tersebut berupa pengembangan perkebunan kelapa sawit, pengembangan pertambangan di wilayah hulunya, pengembangan HTI, aktivitas PETI yang berada di sepanjang sungai Kayan serta limbah rumah tangga yang cenderung besar dari wilayah ibukota kecamatan dan desa. Sungai Kayan memiliki peran yang cukup penting terhadap penyuplai DAS Kapuas melalui Sub Das Melawi. Hal ini dikarenakan sumber air dari Sungai kayan berasal dari wilayah-wilayah perhuluan yang berbatasan secara administrasi. Perbatasan tersebut baik kabupaten maupun provinsi.

Alur sungai kayan terpencar menjalur 5 (lima) jalur yang melalui 2 kecamatan, yaitu Kecamatan Kayan Hilir dan Kayan Hulu. Untuk anak sungai yang berada di Kayan Hulu ialah sungai Payak dam sungai Tebidah. Sedangkan yang mengalir di Kecamatan Kayan Hilir ialah sungai Ingar, sungai Mau dan sungai Kebahan. Sistem hidrologis sungai Kayan ini selain sebagai penyuplai Sub DAS Melawi yang bermuara di DAS Kapuas juga sebagai aktivitas budidaya pertanian maupun aktivitas transportasi penghubung masyarakat yang berada di sekitar Sungai Kayan. Model pemanfaatan yang ditemui di sekitar sungai Kayan dapat dibagi menjadi musiman maupun sepanjang tahun. Untuk pemanfaatan secara musiman, biasanya dengan melakukan aktivitas pertanian, pertambangan rakyat, perikanan, dan transportasi. Sedangkan pemanfaatan sepanjang tahun lebih pada kebutuhan mandi cuci kakus (BPS Sintang, 2013).

\section{METODE PENELITIAN}

Penelitian ini dilakukan pada Bulan Juni - Juli 2018 dengan menggunakan metode Observasi Lapangan dan pengukuruan. Observasi lapangan digunakan untuk memperoleh gambaran secara langsung mengenai kondisi riil sungai Kayan sehingga dapat mentukan titik pengambilan sampel air. Sedangkan metode pengukuran digunakan untuk mengetahui kualitas air Sungai Kayan sesuai dengan indikator-indikator yang telah ditetapkan. 
Analisis Kualitas Air Sungai Kayan Kabupaten Sintang

Analisa sampel air sungai dilakukan sesuai dengan Standar Nasional Indonesia (SNI) untuk setiap parameter uji dan mengacu kepada Peraturan Pemerintah No. 82 Tahun 2001 tentang Pengelolaan Kualitas Air dan Pengendalian Pencemaran Air. Selain menggunakan SNI, pengujian sampel air juga dilakukan menggunakan acuan standar dari alat yang digunakan untuk analisis. Setiap hasil analisis dilakukan kontrol untuk jaminan mutu hasil pengujian.

\section{HASIL DAN PEMBAHASAN}

Pemantauan kualitas air sungai Kayan mengacu pada Peraturan Pemerintah No. 82 Tahun 2001 tentang Pengelolaan Kualitas Air dan Pengendalian Pencemaran Air. Kegiatan pengambilan sampel dan pengujian kualitas air sungai Kayan dapat dilihat pada gambar 4.7. Standar baku mutu air kelas 1 dan kelas 2 dapat dilihat pada tabel 4.5 dan hasil analisa sampel air sungai Kayan dapat dilihat pada Tabel 1, di bawah ini :

Tabel 1. Hasil Analisa Sampel Air Sungai Kayan

\begin{tabular}{|c|c|c|c|c|c|c|}
\hline \multirow[b]{2}{*}{ No } & \multirow[b]{2}{*}{ Parameter } & \multicolumn{5}{|c|}{ NAMA DESA } \\
\hline & & $\begin{array}{l}\text { Lintang } \\
\text { Tambuk }\end{array}$ & $\begin{array}{c}\text { Nanga } \\
\text { Tebidah }\end{array}$ & Nanga Mau & Mentunai & $\begin{array}{l}\text { Sungai } \\
\text { Ranap }\end{array}$ \\
\hline 1. & $\begin{array}{l}\text { Temper } \\
\text { atur }\end{array}$ & 28,5 & 27,6 & 29,0 & 26,8 & 26,6 \\
\hline 2. & TDS & 34 & 28 & 21 & 21 & 19 \\
\hline 3. & TSS & 18,6 & 25,6 & 26 & 27,2 & 23 \\
\hline 4. & Warna & 35 & 50 & 69 & 57 & 52 \\
\hline 5. & Turbidity & 15 & 20 & 30 & 26 & 24 \\
\hline 6. & $\mathrm{pH}$ & 6,25 & 6,30 & 6,42 & 6,7 & 6,4 \\
\hline 7. & $\mathrm{BOD}$ & 4,0 & 3,2 & 4,4 & 4,6 & 3,6 \\
\hline 8. & COD & 26 & 35 & 28,9 & 34 & 16 \\
\hline 9. & $\mathrm{DO}$ & 3,2 & 3,1 & 3,8 & 3,6 & 2,9 \\
\hline 10. & Fosfat & 0,12 & 0,13 & 0,10 & 0,20 & 0,03 \\
\hline 11. & Nitrat & 0,50 & 0,60 & 0,40 & 0,40 & 0,7 \\
\hline 12. & Nitrit & 0,009 & 0,003 & 0,001 & 0,015 & 0,002 \\
\hline 13. & Amoniak & 0,08 & 0,04 & 0,34 & 0,17 & 0,16 \\
\hline 14. & Besi (Fe) & 0,3943 & 0,3375 & 0,1907 & 0,3912 & 0,3785 \\
\hline 15. & $\begin{array}{l}\text { Mangan } \\
(\mathrm{Mn})\end{array}$ & $<0,0084$ & $<0,0084$ & $<0,0084$ & 0,0100 & 0,0138 \\
\hline
\end{tabular}


Analisis Kualitas Air Sungai Kayan Kabupaten Sintang

\begin{tabular}{|c|c|c|c|c|c|c|}
\hline 16. & $\begin{array}{l}\text { Seng } \\
(\mathrm{Zn})\end{array}$ & 0,0141 & 0,1534 & $<0,0233$ & 0,0033 & 0,0020 \\
\hline 17. & $\begin{array}{l}\text { Tembaga } \\
(\mathrm{Cu})\end{array}$ & $<0,0053$ & $<0,0053$ & $<0,0053$ & $<0,0053$ & $<0,0053$ \\
\hline 18. & $\begin{array}{l}\text { Cadmiu } \\
\mathrm{m}(\mathrm{Cd})\end{array}$ & $<0,0012$ & $<0,0012$ & $<0,0012$ & $<0,0012$ & 0,0012 \\
\hline 19. & $\begin{array}{l}\text { Timbal } \\
(\mathrm{Pb})\end{array}$ & 0,1466 & 0,1015 & 0,0434 & 0,1015 & 0,0692 \\
\hline 20. & $\begin{array}{l}\text { Arsen } \\
\text { (As) }\end{array}$ & 0,0003 & 0,0019 & 0,0002 & 0,0008 & 0,0015 \\
\hline 21. & $\begin{array}{l}\text { Merkuri } \\
(\mathrm{Hg})\end{array}$ & 0,0009 & 0,0005 & 0,0009 & 0,0003 & 0,0003 \\
\hline 22. & $\mathrm{Cr}^{6+}$ & 0,0819 & 0,0409 & 0,0966 & 0,0438 & 0,0409 \\
\hline 23. & $\begin{array}{l}\text { Klorida } \\
(\mathrm{Cl})\end{array}$ & 1,5 & 1,10 & 1,9 & 0,7 & 0,7 \\
\hline 24. & $\begin{array}{l}\text { Sianida } \\
(\mathrm{CN})\end{array}$ & 0,007 & 0,009 & 0,003 & 0,007 & 0,004 \\
\hline 25. & $\begin{array}{l}\text { Fluorida } \\
\text { (F) }\end{array}$ & 0,009 & 0,01 & 0,03 & 0,01 & 0,02 \\
\hline 26. & $\mathrm{CL}_{2}$ & 0,005 & 0,005 & 0,09 & 0,004 & 0,001 \\
\hline 27. & $\begin{array}{l}\text { Sulfat } \\
\left(\mathrm{SO}_{4}\right)\end{array}$ & 20 & 23 & 0,0003 & 24 & 10 \\
\hline 28. & $\begin{array}{l}\text { Belerang } \\
\left(\mathrm{H}_{2} \mathrm{~S}\right)\end{array}$ & 0,0032 & 0,004 & 0,019 & 0,009 & 0,004 \\
\hline 29. & $\begin{array}{l}\text { Minyak } \\
\text { dan } \\
\text { Lemak }\end{array}$ & 0,02 & 0,04 & 0,08 & 0,04 & 0,04 \\
\hline 30. & Detergen & 0,04 & 0,03 & 0,07 & 0,07 & 0,02 \\
\hline 31. & Fenol & 0,0007 & 0,0005 & 0,0009 & 0,0005 & 0,0002 \\
\hline 32. & $\begin{array}{l}\text { Fecal } \\
\text { Coliform }\end{array}$ & 23 & 20 & 30 & 28 & 22 \\
\hline 33. & $\begin{array}{l}\text { Total } \\
\text { Coliform }\end{array}$ & 57 & 50 & 60 & 57 & 43 \\
\hline
\end{tabular}

Sumber : Hasil Analisis Data 
Analisis Kualitas Air Sungai Kayan Kabupaten Sintang

1. Total Disollved Suspended (TDS)

TDS adalah kandungan zat padat terlarut yang terdapat dalam air. Air alam mengandung zat padat terlarut yang berasal dari mineral dan garam-garam terlarut ketika air mengalir di bawah atau di permukaan tanah. Kandungan zat padat akan meningkat apabila air dicemari oleh limbah yang berasal dari industri pertambangan dan pertanian. Rendahnya konsentrasi bahan terlarut dalam air akan mengakibatkan pertumbuhan organisme air akan terhambat karena kekurangan nutrisi. Namun, tingginya konsentrasi bahan terlarut dapat menyebabkan eutrofikasi atau matinya jenis-jenis organisme air.

Hasil analisa TDS sampel air sungai Kayan di lima desa yang menjadi titik sampling dapat dilihat pada Gambar 1. Hasil analisa sampel menunjukkan bahwa di lima desa yang menjadi titik sampling pemantauan kualitas air memiliki nilai TDS masih jauh di bawah ambang batas standar baku mutu air kelas 1 (1000 mg/l). Jadi, lima desa di sepanjang DAS Kayan untuk parameter TDS memenuhi kriteria baku mutu air kelas 1 sebanyak $100 \%$.

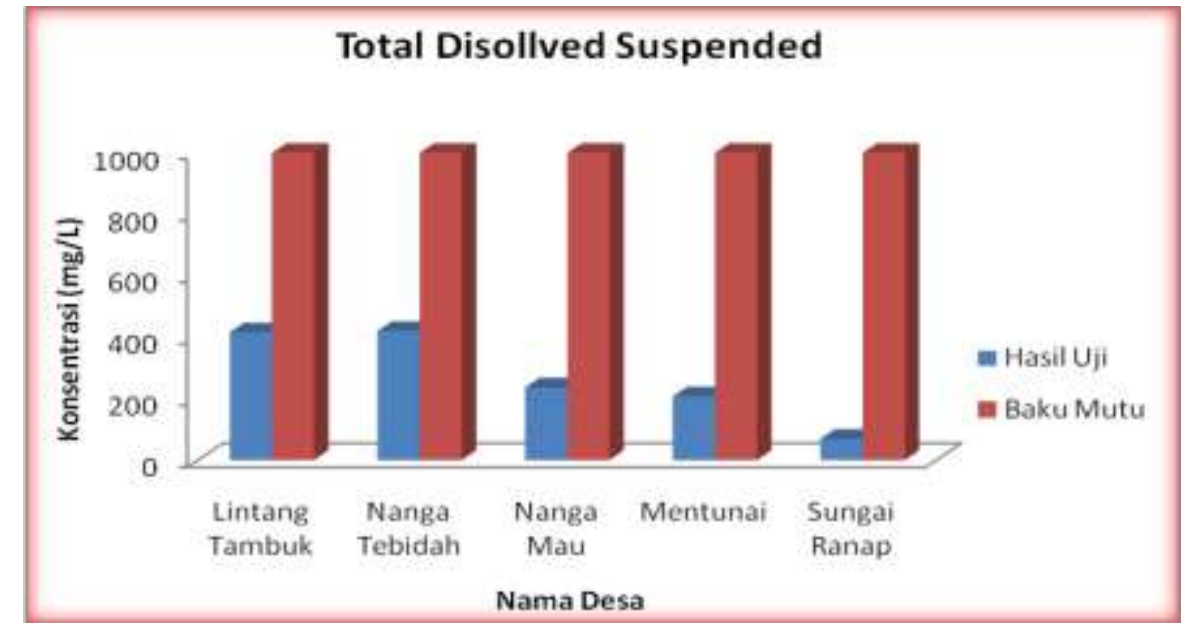

Gambar 1. Grafik parameter TDS pada titik sampling di sungai Kayan 


\section{Dissolved Oxygen (DO)}

DO merupakan oksigen yang ada di dalam air dan berasal dari oksigen di udara dan hasil fotosintesis tumbuhan air. Oksigen sangat dibutuhkan dalam kehidupan hewan dan tumbuhan air. Kandungan oksigen di dalam air lebih sedikit dibandingkan dengan di udara. Oksigen merupakan salah satu gas terlarut di perairan alami dengan kadar bervariasi yang dipengaruhi oleh suhu, salinitas, turbulensi air dan tekanan atmosfir. Selain diperlukan untuk kelangsungan hidup organisme di perairan, oksigen juga diperlukan dalam proses dekomposisi senyawa-senyawa organik menjadi senyawa anorganik.

Apabila penurunan oksigen terlarut tetap berlanjut hingga nol, biota air yang membutuhkan oksigen (aerobik) akan mati, dan digantikan dengan tumbuhnya mikroba yang tidak membutuhkan oksigen atau mikroba anerobik. Sama halnya dengan mikroba aerobik, mikroba anaerobik juga akan memanfaatkan karbon dari bahan organik. Hasil dari respirasi anaerobik ini terbentuk gas metana $\left(\mathrm{CH}_{4}\right)$ dan gas asam sulfida $\left(\mathrm{H}_{2} \mathrm{~S}\right)$ yang berbau busuk. Masuknya zat terlarut lain dalam air mengganggu kelarutan oksigen dalam air.

Kandungan oksigen pada air yang bergerak lebih banyak dibandingkan dengan air yang tergenang. Kandungan oksigen berbeda antar musim, bahkan antar jam dalam satu hari, dan berubah sesuai dengan suhu dan ketinggian tempat. Kekurangan oksigen akan menyebabkan tumbuhan atau hewan air sulit untuk berkembang. Hasil analisa kadar DO air sungai Kayan untuk lima desa yang menjadi titik sampling dapat dilihat pada Gambar 2, berikut ini : 


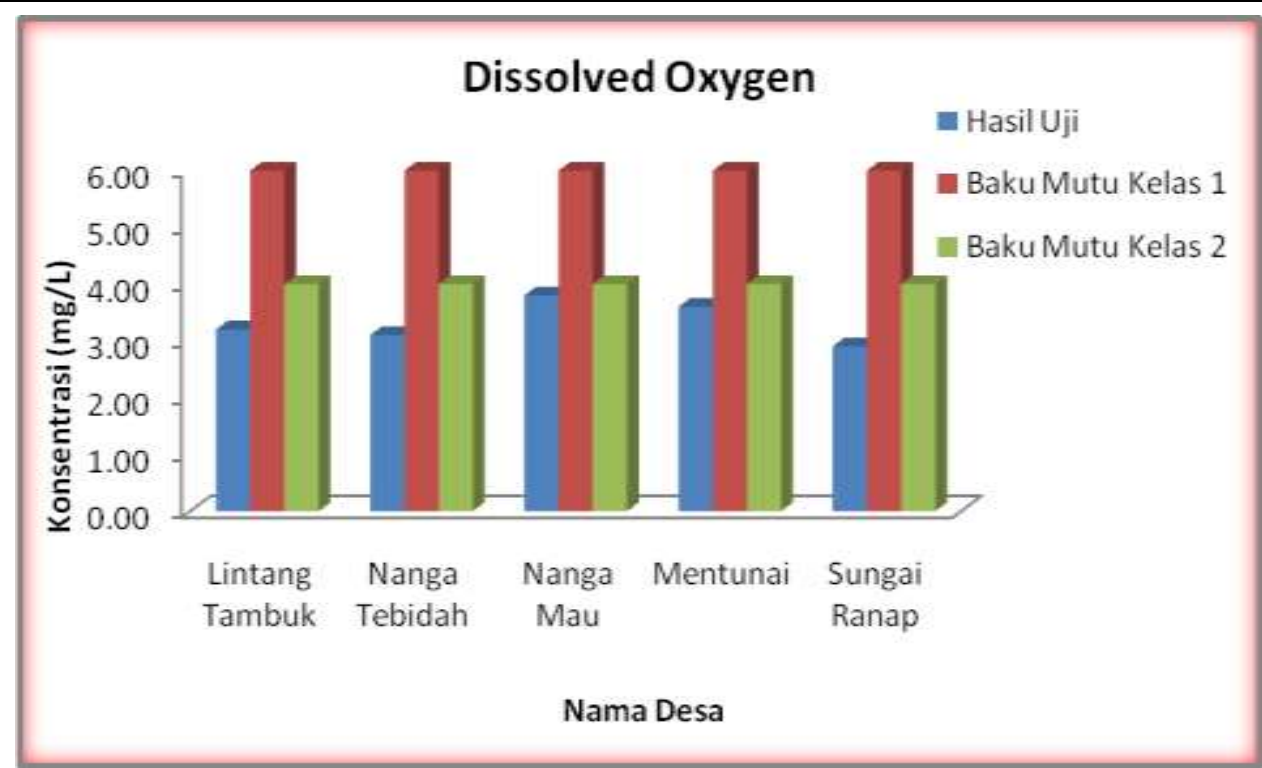

Gambar 2. Grafik parameter DO pada titik sampling di sungai Kayan

Nilai pada grafik menunjukkan bahwa nilai DO air sungai Kayan untuk kelima desa yang menjadi titik sampling di bawah baku mutu kelas I dan II. Hal ini menunjukkan bahwa kadar oksigen di dalam air sungai Kayan berada di bawah ambang batas baku mutu yang dipersyaratkan untuk air minum. Oleh karena itu pemanfaatan lahan pada ekosistem perairan seperti PETI, perkebunan kelapa sawit, sarana transportasi, budi daya ikan, sarana MCK masyarakat setempat, dan limbah organik yang berasal dari limbah domestik lainnya di sepanjang pinggiran sungai Kayan perlu dikelola secara tepat. Hal ini perlu dilakukan agar ekosistem sungai Kayan tidak terganggu. Semakin tinggi nilai DO suatu perairan, maka akan semakin bagus mutu air sungai.

\section{Chemical Oxygen Demand (COD)}

Kebutuhan oksigen kimia (COD) adalah ukuran banyaknya oksigen total dalam satuan milligram per liter yang diperlukan dalam proses oksidasi kimia bahan organik dalam limbah. Analisa nilai 


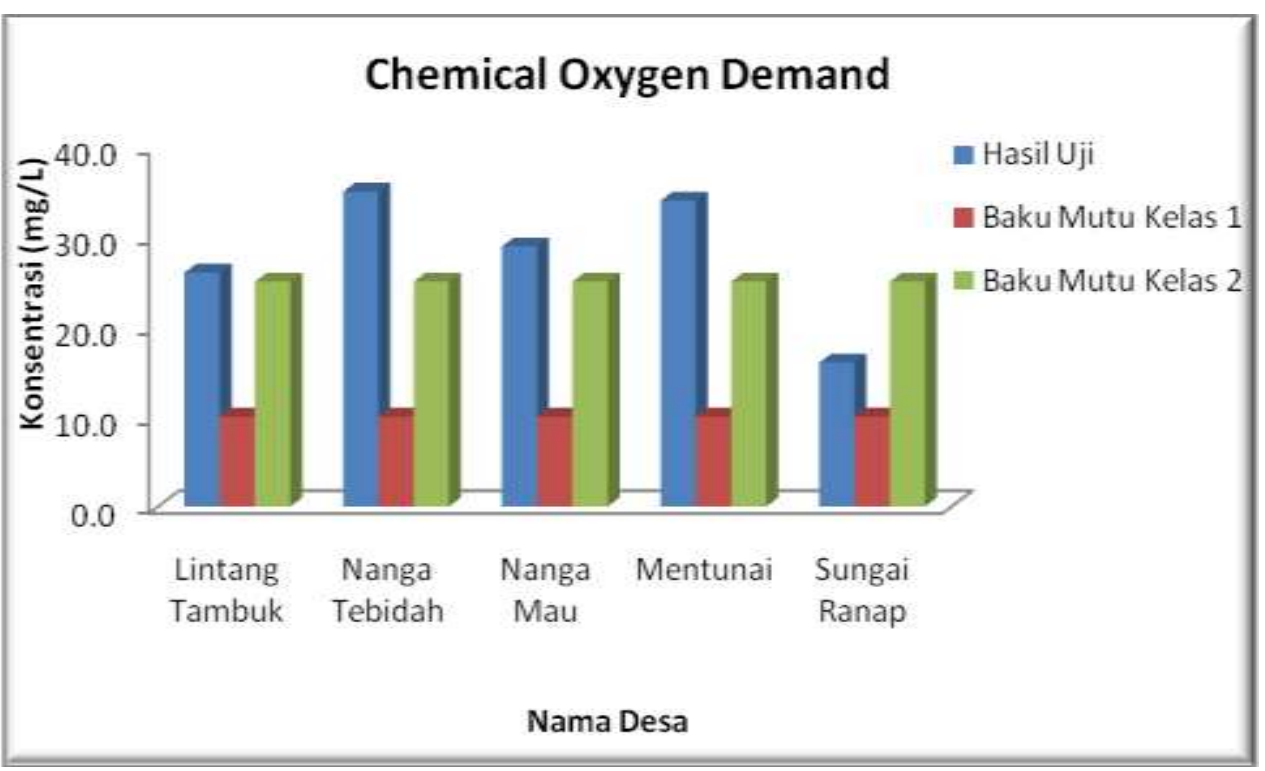

Gambar 3. Grafik parameter COD pada titik sampling di sungai Kayan

Berdasarkan hasil analisis rumah tangga yang kebutuhan oksigen kimia (COD) menghasilkan limbah cair. air Sungai Kayan diketahui Bahan organik yang dibuang bahwa nilai COD untuk air ke perairan sungai Kayanrelatif sungai di desa Sungai Ranap masih berada di bawah baku mutu kelas I, sedangkan keempat desa lainnya yaitu Lintang Tambuk, Nanga Tebidah, Nanga Mau, dan Mentunai berada di atas baku mutu kelas II dan kelas I.

Besarnya nilai COD disebabkan karena aktivitas kegiatan perkebunan kelapa sawit, PETI, perikanan, dan sulit diuraikan secara biologi sehingga harus diuraikan secara kimia. Berdasarkan hasil pengukuran diketahui pula bahwa nilai COD perairan sungai Kayan lebih besar dibandingkan nilai BOD. Hal ini berarti bahwa jumlah senyawa kimia yang dapat dioksidasi secara kimiawi lebih besar dibandingkan dengan oksidasi secara biologi. Fardiaz 
Analisis Kualitas Air Sungai Kayan Kabupaten Sintang

(1992) juga menyatakan bahwa

uji COD biasanya menghasilkan

nilai kebutuhan oksigen lebih

tinggi dari pada uji BOD, karena

bahan-bahan yang stabil

terhadap reaksi biologi dan

mikroorganisme dapat ikut

teroksidasi dalam uji COD.

\section{Biologycal Oxygen Demand} (BOD)

Parameter BOD secara

umum banyak dipakai untuk menentukan tingkat pencemaran air buangan. Penentuan BOD sangat penting untuk menelusuri aliran pencemaran dari tingkat hulu ke hilir (muara). Hasil analisa nilai BOD sungai Kayan dapat dilihat pada Gambar 4.15. Nilai tertinggi BOD terdapat di desa Mentunai yaitu sebesar 4,6 $\mathrm{mg} / \mathrm{L}$, sedangkan nilai BOD terendah terdapat di desa Nanga Tebidah yaitu sebesar 3,2 mg/L. Secara keseluruhan air sungai Kayan tidak ada yang memenuhi kriteria baku mutu kelas 1 dan baku mutu kelas II.

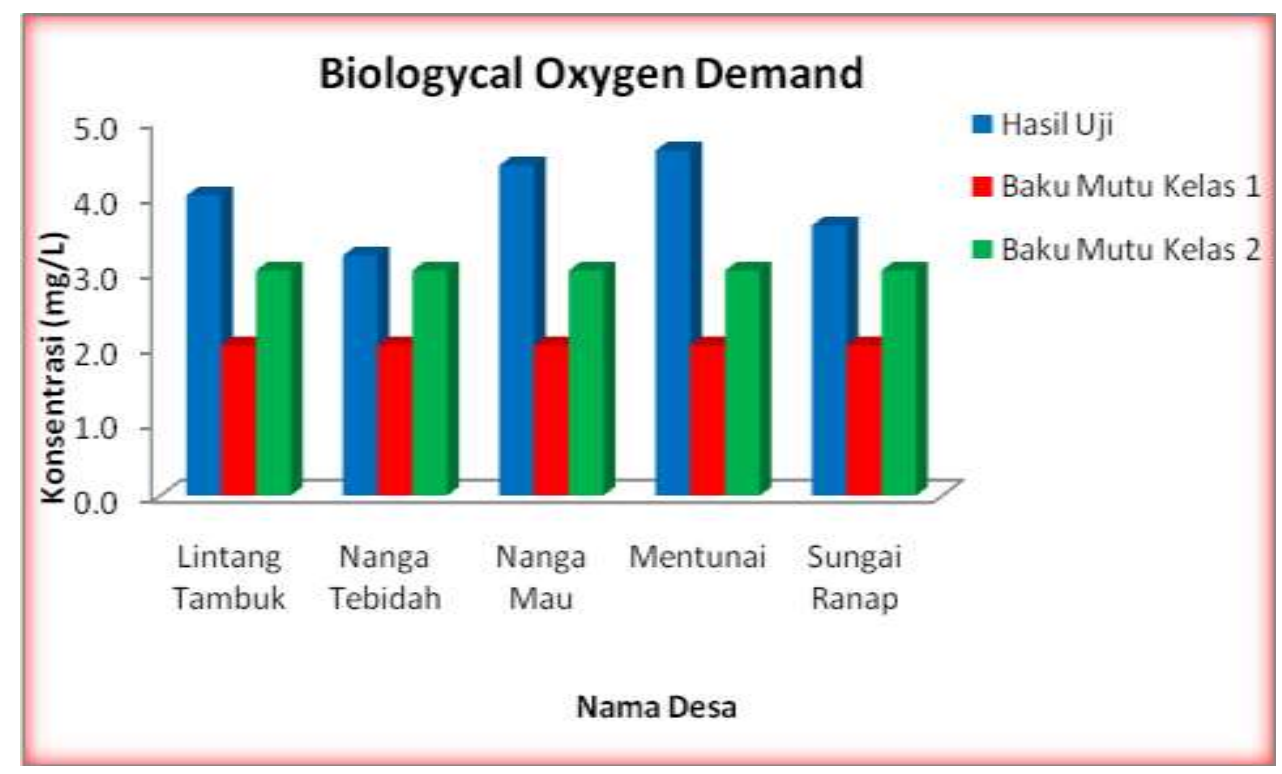

Gambar 4. Grafik parameter BOD pada titik sampling di sungai Kayan

$\begin{array}{ccclcr}\text { Nilai } & \text { BOD } & \text { tertinggi } & & \text { terutama yang berasal dari } \\ \text { disebabkan } & \text { oleh } & \text { karena } & \text { limbah domestik. Nilai BOD } \\ \text { menumpuknya } & \text { limbah } & \text { organik } & \text { terendah diduga } & \text { sebagai }\end{array}$


implikasi dari relatif baiknya proses dekomposisi bahan organik yang dioksidasi oleh mikroba. Pada musim kemarau nilai BOD cenderung lebih tinggi dibandingkan pada musim penghujan. Kondisi ini disebabkan oleh karena adanya pengaruh pengenceran pada musim penghujan yang ditunjukkan dengan debit aliran air yang relatif besar. Nilai BOD tidak menunjukkan jumlah bahan organik yang sebenarnya, tetapi hanya mengukur secara relatif jumlah oksigen yang dibutuhkan untuk mengoksidasi bahan-bahan buangan.

\section{Logam Berat $\mathrm{Cd}, \mathrm{Cr}, \mathrm{Pb}$,}

\section{$\mathrm{Cu}, \mathrm{Hg}$ dan $\mathrm{Fe}$}

Hasil analisa menunjukkan bahwa sebanyak lima desa yang menjadi titik sampling memiliki nilai konsentrasi kadmium di dalam sampel air masih di bawah baku mutu air kelas 1 yaitu kurang dari 0,0012 mg/L. hal ini menunjukkan bahwa sungai Kayan belum tercemar oleh logam berat kadmium. Konsentrasi kadmium maksimum dalam air minum yang diperbolehkan oleh Depkes RI dan WHO adalah $0,01, \mathrm{mg} / \mathrm{l}$.

Hasil analisa sampel air sungai pada lima desa menunjukkan bahwa dua desa yang menjadi titik sampling tersebut memiliki kadar kromium (Cr) terlarut di atas baku mutu air kelas 1 dan II yaitu desa Lintang Tambuk sebesar 0,0819 mg/L dan desa Nanga Mau sebesar 0,0966 $\mathrm{mg} / \mathrm{L}$.

Hasil analisa sampel air sungai pada lima desa menunjukkan bahwa lima desa yang menjadi titik sampling tersebut memiliki kadar timbale $(\mathrm{Pb})$ terlarut berada di atas baku mutu kualitas air kelas $1(0,03$ $\mathrm{mg} / \mathrm{l})$ dan air kelas $2(0,03 \mathrm{mg} / \mathrm{l})$.

Hasil analisa sampel air sungai pada lima desa menunjukkan bahwa kelima desa yang menjadi titik sampling tersebut memiliki kadar tembaga $(\mathrm{Cu})$ terlarut masih rendah yaitu kurang dari 0,0053 mg/L. Hal ini berarti bahwa air sungai Kayan memiliki kandungan logam tembaga terlarut di bawah ambang 
Analisis Kualitas Air Sungai Kayan Kabupaten Sintang

batas baku mutu air kelas $1(0,02$ $\mathrm{mg} / \mathrm{l})$ dan air kelas $2(0,02 \mathrm{mg} / \mathrm{l})$.

Analisis air menunjukkan kadar merkuri $(\mathrm{Hg})$ yang kecil atau berada di bawah ambang batas baku mutu air kelas 1 (0,001 mg/L) dan baku mutu air kelas $2(0,002 \mathrm{mg} / \mathrm{L})$ dikarenakan pengujian dilakukan pada air permukaan. Di mana air memiliki berat jenis lebih kecil dibandingkan merkuri sehinggga merkuri mengendap di dasar sungai.

Hasil analisa menunjukkan bahwa kadar besi $(\mathrm{Fe})$ terlarut air sungai Kayan pada keempat desa yang menjadi titik sampling tersebut berada di atas ambang batas standar baku mutu air kelas 1 (0,3 mg/l). Oleh karena itu, kualitas air sungai Kayan pada semua kecamatan $100 \%$ berada pada kelas 2 dan tidak layak untuk dijadikan bahan baku air minum.

\section{KESIMPULAN}

Berdasarkan hasil penelitian dapat disimpulkan bahwa :

1. Berdasarkan hasil analisis air sungai Kayan bahwa kelima desa yang menjadi titik sampling di sepanjang aliran sungai Kayan menunjukkan bahwa untuk parameter Chemical Oxygen Demand (COD), Biologycal Oxygen Demand (BOD), Warna, Kekeruhan, kandungan logam besi $(\mathrm{Fe})$, dan logam timbale $(\mathrm{Pb})$ telah melebihi ambang batas baku mutu kualitas air kelas 1 dan 2.

2. Air sungai Kayan sudah tidak memenuhi kriteria baku mutu air kelas 1 sehingga tidak layak untuk menjadi bahan baku air minum bagi masyarakat setempat.

\section{DAFTAR PUSTAKA}

Badan Pusat Statistik, 2014, Kecamatan Kayan Hilir Dalam Angka, BPS Sintang.

Badan Pusat Statistik, 2013, Kabupaten Sintang Dalam Angka, BPS Sintang.

Badan Pusat Statistik, 2011, Kecamatan Kayan Hulu Dalam Angka, BPS Sintang.

Badan Lingkungan Hidup, 2014, Pengembangan Data dan Informasi Lingkungan Maping Sumber Daya Air Tahap III, BLH, Sintang. 
Analisis Kualitas Air Sungai Kayan Kabupaten Sintang

Lusiana, B., dkk, 2008, Kajian

Kondisi Hidrologi DAS

Kapuas Hulu, Kabupaten
Kapuas Hulu, Kalimantan

Barat, World Agroforestry

Centre, Bogor. 